\title{
产教融合视角下职业教育政校行企协同育人机制构建研究 一一德合作双元制本科项目的创新与实践
}

Study on the Mechanism of Collaborative Education of Vocational Education from the Perspective of Integration of Industry and Education

- Innovation and Practice of the Sino German Cooperative Undergraduate Program

\section{严红霞}

Hongxia Yan

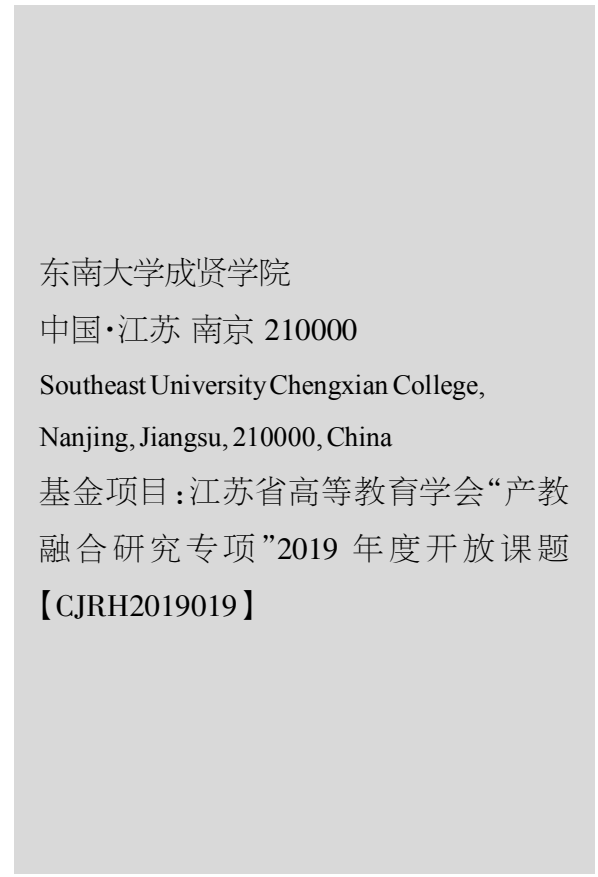

【摘 要】建立“政校行企”四位一体协同育人的人才培养机制, 不仅需要打破传统高校人 才培养同质化的惯性,还需要通过体制创新破除制约产教融合发展的瓶颈。论文从高校产 教融合的背景出发, 分析当前高校产教融合普遍存在的问题, 以中德合作双元制本科项目 为案例,从政府、高校、企业、行业 4 个层面,提出产教融合的改革思路。

【Abstract \In order to set up the personnel training mechanism of the "four-in-one integration of government, school and enterprise", people not only need to break the traditional inertia of the homogenization of personnel training in colleges and universities, but also need to break the bottleneck of the integration of production and education through the innovation of the system mechanism. Based on the background of the integration of Industry and education in colleges and universities, this paper analyzes the common problems existing in the integration of industry and education in colleges and universities. The reform thinking of the integration of production and education is put forward.

【关键词】产教融合; 政校行企;协同育人;双元制

【Keywords】integration of industry and education; administration, school and enterprise; collaborative education; dual system

【DOI】10.36012/sde.v2i1.756

\section{1 引言}

推动地方普通本科高校向应用型转型，深化产教融合已 成为中国高等教育改革的必然趋势。为促进教育链、人才链与 产业链、创新链有机衔接，国务院办公 2017 年 12 月发布的 《关于深化产教融合的若干意见》(国办发〔2017 995 号), 明确
了产教融合的总体目标, 对推进 “产教融合发展工程”提出了 新的要求。江苏省颁布《关于深化产教融合的实施意见》(苏政 办发 [2018]48 号)。2019 年 1 月,国务院发布重磅文件《国家 职业教育改革实施方案》,引导一大批普通本科高等学校向应 用型转变,开启新一轮的产教融合发展新征程。构建“政校行 企”协同育人机制, 创新产教协同育人体系, 是应用型人才培 
养的有效途径。

\section{2 应用型高校产教融合的背景和意义}

新经济发展给应用型高校的转型发展带来了新机遇。当 前, 大数据、人工智能等科技创新影响了产品的生命周期全过 程,迫切需要优化人才培养结构,应用型、复合型创新型人才 紧缺。2015 年 11 月,教育部发布《教育部关于本科高校向应 用型转变的指导意见》[11中指出,地方高校要积极推进转型发 展, 提高职业教育水平, 建设应用型本科高校。高校必须主动 对接新经济、新业态, 以行业企业需求为导向,立足于地区经 济发展, 优化专业结构,创新人才培养模式, 找准服务地方产 业发展的切入点, 走特色发展、错位发展的道路,为“中国制造 2025 ”提供人才支撑 ${ }^{[2]}$

\section{3 新工科建设对应用型人才培养提出了}

\section{新要求}

围绕国家战略和区域发展需要, 为适应新一轮产业变革 的新趋势, 教育部实施新工科发展战略。新工科对接人工智 能、智能制造等新兴产业，运用现代信息手段对传统工科进行 信息化改造,从以学科为导向到以产业需求为导向转变,产学 研合作是新工科建设的必然选择。为适应行业产业的新变革, 应用型高校要以新工科建设为契机, 坚持“学生中心、产出导 向、持续改进”的“新理念”[1]，紧密对接经济带、城市群和产业 链, 实现学科交叉融合、专业改造升级, 将产教融合、协同育人 作为应用型人才培养的主要途径。

\section{4 产教融合是应用型高校转型发展的关键}

应用型高校的转型发展必须立足区域经济社会的发展需 求, 提升人才培养的质量, 发挥教育对产业转型升级的支撑引 领作用, 助力经济转型升级。产教融合已成为促进职业教育、 高等教育发展并加强创新型人才和技术技能型人才培养的重 要举措,成为统筹推进教育综合改革的制度安排。

\section{5 应用型高校产教融合的困境分析}

\section{1 高校人才培养目标定位同质化倾向明显}

中国地方普通本科高校的分类不清、定位不明,在专业设 置、科学研究、社会服务等方面追求学术型、研究型发展,办学 同质化倾向明显,背离了区域经济社会发展的人才需求,导致 人才培养与社会需求脱节，与区域企业人才缺失严重的结构 性矛盾突出,难以形成对产教融合的支撑。

\section{2 政府在产教融合中角色定位模糊}

产教融合是学校、企业、行业、政府深入融合协同育人的 
形成了合作共赢的需求动力机制和协同联动平台。我校应用 型人才的培养定位, 决定校企深度合作; 德国双元制的培养模 式的输出, 旨在培养本土化的高层次技术管理人才, 为企业发 展提供人才支持; 对于企业来说, 旨在精准培养高层次技术管 理人才; 政府在引进德资企业的同时, 还引入了双元制教育模 式,为企业发展提供人才支撑。“政校行企”各方主体积极参 与, 建立保障机制, 建立规范的规章制度, 实施运行情况良好。

\section{2 创新人才培养模式,建立“政校行企”四方联 合培养平台}

通过建立搭建“政校行企”四方联合培养平台,校内理论 教学与企业实习实训相结合, 专业教育与职业教育相结合, 培 养高层次技术管理人才, 满足区域经济发展需求。

理论学习阶段通过通识教育、科学基础教育、机械专业知 识教育和经济管理专业教育培养学生的人文素质、科学素养、 专业能力; 企业实践阶段通过参加企业轮岗和项目实训, 注重 职业技能训练和职业素养提升。通过理论到实践,专业教育与 职业教育相结合, 注重培养学生的专业能力、职业能力、创新 意识,真正实现毕业与就业的“零距离”对接, 实现企业人才的 个性订制、满足学生的多元发展, 应用型人才培养成效显著。

\section{3 校企共建设双师型教学团队,引入国际化师}

\section{资与企业人力资源}

师资队伍建设是人才培养的基础，引入国际化师资和企 业资深专家才队,校企共建高学历、强工程实践能力的“两高 一强”双师型师资队伍。

一方面,在企业实训期间, 实践经验丰富的高水平工程 师进行学徒式指导; 另一方面, 学校引进实战经验丰富的工 程技术人员, 提高了高校教师的工程素养和实践能力。同时, 依托太仓德资企业的人力资源和德国双元制大学的师资,引 进了国际化师资,以“亿迈齿轮”为代表的德资企业的外籍培 训师, 在实习期间给学生提供高水平的指导。国际化和企业
国内外动态研究 The National and International Dynamic Research

人力资源相结合的师资团队, 为本项目的教学质量提供了支 撑和保障。

\section{4 构建“两大平台、三个结合、四个层次”、依托 产业集群的实践教学体系}

中德合作双元制本科项目以培养学生的工程实践与创新 能力为导向, 依托机械产业集群,打造校内企业两大实践教学 平台, 实现校内与校外相结合、课堂与企业相结合的模式, 搭 建基本技能培养层、综合能力培养层、工程应用能力培养层和 创新能力训练层的多层次结构,形成了“两大平台、三个结合、 四个层次”的实践教学体系。

\section{5 文化育人,实践育人,建立全方位、多元化的}

\section{育人体系}

中德合作双元制本科项目积极文化育人,实践育人,建立 了全方位、多元化的育人体系。坚持理论学习、创新思维与社 会实践相统一,培养学生勇于探索的创新精神、善于解决问题 的实践能力。中德合作双元制本科项目依托企业的文化氛围 和制造业行业特色，实施“贴合社会需求，突出专业特点，适应 个性发展”的全方位、多元化实践育人体系。以圣诞节、感恩 节、企业年会、企业周年庆等多元化载体，组织各项专业汇报、 文化活动, 以达到实践育人和立德树人的工作目标。

\section{参考文献}

[1]教育部、国家发展改革委、财政部.关于引导部分地方普通本 科高校向应用型转变的指导意见[EB/OL].(2015-10-23)[2019-10-12] http:/www.moe.edu.cn/srcsite/A03/moe_1892/moe_630/201511/t201511 13 218942.html.

$[2]$ 凤权. OBE 教育模式下应用型人才培养的研究 [J].安徽工程大 学报,2016,31(3):81-85

[3]中华人民共和国教育部.关于加快建设高水平本科教育 全面 提高人才培养能力的意见 [EB/OL].(2018-10-17)[2019-10-12].http: //www.moe.edu.cn/srcsite/A08/s7056/201810/t20181017_351887.html. 